\title{
ESTUDO DE CASO SOBRE A REPERCUSSÃO DA DISCIPLINA DE SOCIOLOGIA EM UMA ESCOLA NO INTERIOR DO CEARÁ: ANÁLISE DO TEMA DESIGUALDADE RACIAL
}

\author{
Case study on the repercussion of the discipline of sociology in a \\ school in the interior of Ceará: analysis of the racial inequality theme
}

\author{
Márcio Kleber Morais Pessoa' \\ Manoel Moreira de Sousa Neto ${ }^{2}$
}

\begin{abstract}
Resumo:
0 objetivo deste texto é analisar a repercussão da disciplina de Sociologia em turmas de ensino médio de uma escola pública do interior do Ceará, acerca do tema da Desigualdade racial, por meio de um estudo de caso. Iremos refletir sobre a repercussão das aulas da disciplina com relação à apreensão de habilidades e competências dos alunos em relação ao tema abordado. A metodologia está assentada no estudo de caso com aplicação de questionários com alunos participantes, antes e depois das aulas de sociologia; observações no ambiente escolar; revisão de literatura; e análise documental. Entre os principais resultados, destacamos que os alunos apresentaram respostas críticas ao tema em maior quantidade entre a $1^{\text {a }}$ e a $2^{\text {a }}$ fases da pesquisa. Houve relativo êxito na intervenção da disciplina de sociologia em relação à desconstrução do mito da Democracia racial. 0 contexto da pesquisa também aponta que a disciplina de sociologia é apenas um aspecto da socialização dos alunos, não podendo sozinha desconstruir os discursos ideológicos, os mitos e as pré-noções ligados ao tema.
\end{abstract}

Palavras-chave: Sociologia no Ensino Médio; Escola pública; Desigualdade racial; Democracia racial.

\begin{abstract}
:
The aim of this text is to analyze the repercussion of the discipline of Sociology in high school classes of a public school in the interior of Ceará on the subject of racial inequality, through a case study. We will reflect on the repercussion of the classes of the discipline in relation to the apprehension of abilities and competences of the students in relation to the topic addressed. The methodology is based on the case study with application of questionnaires with participating students, before and after the classes of sociology; observations in the school environment; literature review; and documentary analysis. Among the main results, we highlight that the students presented critical answers to the topic in greater quantity between the 1 st and 2 nd phases of the research. There was a relative success in the

\footnotetext{
1 Graduado em Ciências Sociais e mestre em Sociologia pela Universidade Federal do Ceará (UFC). Doutorando em Sociologia pela Universidade Estadual do Ceará (UECE). Professor efetivo de Sociologia da rede estadual de educação básica do Ceará. E-mail: mkpceara@hotmail.com / ORCID: https://orcid.org/0000-0002-1371-5481 Cidade: Fortaleza.

2 Graduado em Ciências Sociais e mestre em Sociologia pela UFC. Doutorando em Sociologia pela Universidade Federal do Paraná (UFPR). Professor efetivo de Sociologia da rede estadual de educação básica do Ceará. E-mail: manoelneto81@hotmail.com / ORCID: https://orcid.org/0000-0003-25481966 Cidade: Fortaleza.
} 
A repercussão da disciplina de Sociologia em uma escola no interior do Ceará | Márcio Kleber M. Pessoa \& Manuel Moreira de S. Neto

intervention of the discipline of sociology in relation to the deconstruction of the myth of racial democracy. The context of the research also points out that the discipline of sociology is only one aspect of students' socialization, and cannot deconstruct the ideological discourses, myths and preconceptions related to the subject.

Keywords: Sociology in High School. Public school. Racial inequality. Racial democracy.

\section{Introdução}

O objetivo deste texto é analisar a repercussão da disciplina de sociologia no ensino médio acerca da análise do tema Desigualdade racial, por meio de um estudo de caso. A pesquisa foi realizada em uma escola de ensino médio pertencente à rede estadual de educação básica do Ceará, localizada no interior do estado ${ }^{3}$. Os participantes da pesquisa são alunos e alunas das $1^{\text {a }}$ séries da escola. No total, há três turmas de $1^{\text {a }}$ série na escola, perfazendo o número de 88 matrículas. Contudo, segundo dados colhidos em campo, apenas 74 frequentavam regularmente as aulas no periodo da investigação. A pesquisa foi realizada com todos os alunos da $1^{\text {a }}$ série na escola, entre novembro e dezembro de 2016.

Dito isso, os objetivos específicos são: (1) refletir sobre a repercussão das aulas da disciplina de Sociologia e acerca da apreensão de habilidades e competências dos alunos em relação ao tema abordado; (2) analisar a prática docente em Sociologia; (3) apresentar as discussões sobre o tema Desigualdade racial nas aulas de sociologia com os alunos participantes; (4) descrever as aulas ministradas aos participantes da pesquisa, destacando assuntos, métodos, dados e discussões realizadas; e (5) comparar os conhecimentos dos alunos participantes da pesquisa, antes e depois das aulas referentes ao tema abordado.

Os procedimentos metodológicos empregados para se alcançar os objetivos propostos foram: aplicação de questionários com alunos participantes, antes e depois das aulas de sociologia no ensino médio, referentes ao tema Desigualdade racial, a fim de aferir e comparar as visões dos alunos sobre o assunto nos dois momentos indicados, buscando analisar as possiveis mudanças de visão advindas das aulas; observações no

\footnotetext{
3 A escolha dessa escola ocorreu visando a exequibilidade da pesquisa, visto que os pesquisadores, devido à sua rede de relações prévias, mantinham contato profissional com o professor de Sociologia do estabelecimento educacional, o que lhes garantiu a inserção no campo.
} 
A repercussão da disciplina de Sociologia em uma escola no interior do Ceará | Márcio Kleber M. Pessoa \& Manuel Moreira de S. Neto

ambiente escolar, principalmente nas aulas sobre o tema, com a realização de descrição dos métodos empregados e assuntos debatidos; revisão de literatura sobre o tema Desigualdade racial e sociologia no ensino médio; e, por fim, análise documental (CELLARD, 2014) referente à disciplina de sociologia no ensino médio.

Estes métodos e técnicas de pesquisas possibilitaram a realização do estudo de caso aqui apresentado. Goldenberg diz que, por meio do estudo de caso,

se pode adquirir conhecimento do fenômeno estudado a partir da exploração intensa de um único caso [...] e complementa: o estudo de caso reúne o maior número de informações detalhadas, por meio de diferentes técnicas de pesquisa, com o objetivo de apreender a totalidade de uma situação e descrever a complexidade de um caso concreto (GOLDENBERG, 2004, p. 33-4).

Conforme destaca a autora, o estudo de caso é a "exploração intensa" de um caso específico. O estudo apresentado neste texto converge com a exposição de Goldenberg, visto que o caso da escola estudada foi intensamente explorado pelos autores, por meio daquelas técnicas e métodos descritos anteriormente. Durante dois meses, os pesquisadores estiveram por diversas vezes na escola, em contato com alunos, professores e gestores escolares. A aplicação de questionários, antes e depois das aulas sobre Desigualdade racial e as observações, indicam a tentativa de "apreender a totalidade" da situação com o objetivo de "descrever a complexidade" do caso.

Vale ressaltar que, segundo Yin (2001, p. 29), os estudos de caso "são generalizáveis a proposições teóricas, e não a populações ou universos. Nesse sentido, o estudo de caso [...] não representa uma amostragem, e o objetivo do pesquisador é expandir e generalizar teorias (generalizações analíticas)". Dito isso, este texto realizará análises sobre um caso específico, a fim de que a generalização dessas análises possa contribuir para discussões sobre o tema, pavimentando o caminho para uma análise mais completa da prática pedagógica da docência em sociologia. Dessa forma, não existe a pretensão de que este artigo sirva para generalizações estatísticas e estudo de populações, pois, por exemplo, não há relevância estatística nos questionários aplicados aos alunos. 
A repercussão da disciplina de Sociologia em uma escola no interior do Ceará | Márcio Kleber M. Pessoa \& Manuel Moreira de S. Neto

\section{Perfil dos participantes da pesquisa}

O primeiro questionário foi aplicado no dia 03 de novembro de 2016, com todos os alunos que estiveram presentes na aula; no total, 71 (setenta e um). Os dados analisados nesse tópico são referentes àquele questionário em que $87 \%$ deles tinham 15 ou 16 anos. $O$ restante tinha 17 anos ou mais. Além disso, $70 \%$ eram católicos e $26 \%$ protestantes. O sexo dos participantes ficou dividido assim: 54\% feminino e 46\%, masculino.

Foi feita uma pergunta aberta sobre a cor de cada aluno e $73 \%$ responderam categorias como moreno (10), pardo (36), preto (2) e negro (4), que se encaixam na categoria analítica "negro". Os demais se identificaram como branco, amarelo ou indígena. Esse dado coincide exatamente com o da questão orientada por itens realizada após aquela: os mesmos $73 \%$ se identificaram como pretos ou pardos, categorias englobadas por "negro". Os dados indicam ainda que a grande maioria dos alunos se identifica por meio de categorias "embranquecedoras", como "moreno" e "pardo", classificação típica da sociedade brasileira, que se identifica pela cor da pele, abrindo margem para relativizações. O método de ter dois tipos de perguntas sobre a cor converge com a prática de pesquisadores e institutos de pesquisa que visam a ofertar meios para que o participante se autodefina livremente por meio de categorias sociais comumente utilizadas em seu dia a dia, para só depois responder a itens elaborados por agentes externos. Vale ressaltar que os negros participantes da pesquisa são em maior número do que na sociedade brasileira em geral, que possui uma taxa de $51 \%$ de pessoas negras.

Sobre a escolaridade de pais e mães, $10 \%$ destas são analfabetas, contra 5,6\% daqueles. Quanto ao grau de instrução, 46\% delas têm ensino fundamental completo ou incompleto, contra $41 \%$ deles. Menos de $9 \%$ das mães e apenas $7 \%$ dos pais têm ensino superior completo ou incompleto. Logo, os dados indicam baixa escolaridade desses parentes. Isso se reflete diretamente na renda familiar mensal dos discentes, a saber: 
A repercussão da disciplina de Sociologia em uma escola no interior do Ceará | Márcio Kleber M. Pessoa \& Manuel Moreira de S. Neto

Tabela 01 - renda familiar mensal dos alunos participantes da pesquisa

\begin{tabular}{c|c|c|c|c|c}
\hline $\begin{array}{c}\text { Faixa de } \\
\text { renda }\end{array}$ & $\begin{array}{c}\text { Até meio } \\
\text { salário mínimo }\end{array}$ & $\begin{array}{c}\text { De meio a um } \\
\text { salário }\end{array}$ & $\begin{array}{c}\text { De um a dois } \\
\text { salários } \\
\text { mínimos }\end{array}$ & $\begin{array}{c}\text { De dois a três } \\
\text { salários mínimos }\end{array}$ & $\begin{array}{c}\text { Mais de três } \\
\text { salários } \\
\text { mínimos }\end{array}$ \\
\hline Resultados & $10,5 \%$ & $34,2 \%$ & $36,8 \%$ & $7,9 \%$ & $10,5 \%$ \\
\hline
\end{tabular}

Fonte: questionário aplicado em campo.

A tabela 01 indica que $81,5 \%$ das famílias dos alunos ganham até dois salários-mínimos de renda mensal. Este dado incide diretamente no gozo do direito à renda mínima ofertada pelo governo, o Bolsa Família. Dessa forma, $69 \%$ dos alunos afirmam que suas famílias recebem esse benefício.

Como se pode perceber, o perfil do aluno participante da pesquisa é, em geral, o seguinte: negro, com pai e mãe de baixa escolaridade, de família pobre e, devido a isso, usuário de serviços e benefícios do governo. Devido a esse perfil, é coerente o fato de $45 \%$ dos participantes afirmarem já ter sofrido alguma ação racista. A seguir, discutiremos o processo de aplicação do primeiro questionário, importante dado de pesquisa.

\section{Raça, silêncio e lágrimas: primeira rodada de questionários}

Lilia Schwarcz, uma das principais autoras sobre a temática Desigualdade racial no Brasil, escreveu em seu livro "Nem preto nem branco, muito pelo contrário" (SCHWARCZ, 2012) que a discussão sobre "nossos exóticos produtos culturais mestiços", dentro do país, "é quase um tabu", predominando o silêncio sobre o assunto em nosso cotidiano. A realização da pesquisa que deu origem a este texto converge com a afirmação da autora.

No dia da aplicação do primeiro questionário ${ }^{4}$, logo na primeira turma, quando o professor leu a última afirmativa do questionário, a qual cada aluno deveria responder seu grau de concordância ou discordância 5 , uma aluna, que o pesquisador identificou como sendo negra, começou a chorar e os alunos ao seu redor disseram ao professor que ela estava passando mal. O docente pediu que a aluna saísse de sala, a fim de buscar

\footnotetext{
4 Os questionários eram anônimos, isto é, não tinham espaço para identificação. O anonimato e seu caráter protetivo foi destacado pelos pesquisadores de forma verbal, antes da aplicação. Foi destacado ainda que aquele questionário não tinha nenhuma relação com a avaliação de conhecimento da disciplina de sociologia. Ademais, foi deixado claro aos alunos e às alunas que não se queria saber suas opiniões individuais, mas sim as opiniões coletivas das turmas.

5 Itens disponiveis para a afirmação: discordo plenamente, discordo parcialmente, nem discordo nem concordo, concordo parcialmente e concordo plenamente.
} 
A repercussão da disciplina de Sociologia em uma escola no interior do Ceará | Márcio Kleber M. Pessoa \& Manuel Moreira de S. Neto

apoio com o Núcleo Gestor da escola. Logo em seguida, o professor saiu junto com outra aluna para saber como estava aquela discente. Ela chorava muito e não conseguia consolo. Uma professora que estava no pátio da escola viu a cena e conversou em particular com a aluna. A docente disse em outro momento que a aluna verbalizou que chorava porque estava com fome. Contudo, o fato de a aluna ter chorado exatamente no momento em que respondia à afirmação "Brancos são de uma raça superior à dos negros" levantou a suspeita no pesquisador de que havia uma relação direta entre seu estado emocional e o questionário.

Após alguns minutos de conversa com o professor e a professora, a aluna retornou para a sala de aula e finalizou seu questionário. Encerrada a aplicação, o professor aproveitou para falar à turma que o assunto era "delicado", mas que havia a necessidade de discuti-lo, vislumbrando que entendessem as razões das desigualdades entre negros e brancos no Brasil, pois essa era uma forma de superar tais desigualdades.

Schwarcz destaca ainda que, como o tema não é abordado seriamente e massivamente no país, é como se atitudes racistas fossem "minoritárias e excepcionais: na ausência de uma politica discriminatória oficial, estamos envoltos no país de uma 'boa consciência', que nega o preconceito ou o reconhece como mais brando". Nesse sentido, 97\% dos participantes da primeira aplicação de questionários da pesquisa não se consideram racistas. Contudo, 34\% dizem já ter praticado alguma ação que consideram racista. É como se tais ações não se caracterizassem como ações discriminatórias estruturais, e, sim, ações de cunho pessoal, e, por isso, brandas. (SCHWARCZ, 2012).

Para completar, enquanto $97 \%$ não se consideram racistas, $89 \%$ afirmam já ter presenciado ações racistas de outras pessoas. A máxima de Schwarcz (2012, p. 30-1) se aproxima desse cenário: "todo brasileiro parece se sentir [...] como uma ilha de Democracia racial, cercado de racistas por todos os lados", ou o que a autora chama de "um preconceito do outro".

Como se pode perceber, as características do grupo analisado em relação ao tabu da discussão do tema estudado, apesar de ser composto por maior quantidade de negros, convergem com as caracteristicas da sociedade brasileira, logo, as aulas de sociologia tiveram que ter ritmo e métodos 
A repercussão da disciplina de Sociologia em uma escola no interior do Ceará | Márcio Kleber M. Pessoa \& Manuel Moreira de S. Neto

diferenciados. Mas será o grupo analisado de fato diferenciado acerca da Desigualdade racial? Para saber isso, serão discutidos adiante outros resultados.

\section{Democracia racial: qual igualdade?}

Neste tópico, serão analisadas questões que visam à discussão acerca do mito da Democracia racial. Segundo Antonio Sérgio Guimarães, em prefácio escrito ao livro de Florestan Fernandes, "A integração do negro na sociedade de classes", em meados do século XX, surgiu no Brasil a ideia de que a escravidão por aqui foi mais suave, mais branda. Havia intimidade entre senhor e escravo. Essa ideia aproximava dominados e dominantes na relação entre negros e brancos (FERNANDES, 2008, p. 11). Nesse sentido, no período destacado, havia uma minimização das diferenças raciais (GUIMARÃES, 2003). Com o fim do regime escravista e a inauguração da ordem competitiva capitalista, a condição do negro na sociedade brasileira poderia se igualar à do branco. Contudo, segundo Fernandes, em estudo realizado na cidade de São Paulo, essa nova ordem não se implantou de forma instantânea e homogênea. A ordem econômica capitalista se desenvolveu rapidamente, mas a ordem social, não; havendo resistência à mudança da ordem social escravocrata, havendo exclusão do negro da sociedade de classes e da ordem social competitiva.

\footnotetext{
A degradação da escravidão, a anomia social, a pauperização e a integração deficiente combinaram-se entre si para engendrar um padrão de isolamento econômico e sociocultural do negro e do mulato que é aberrante em uma sociedade "competitiva", "aberta" e "democrática" (FERNANDES, 2008, p. 301-2).
}

Como se pode compreender, o negro não foi incluído na sociedade de classes recém-inaugurada, logo, ainda segundo o autor, o branco não precisou lançar mão de intolerâncias e ódios raciais abertamente, não havendo sinais de luta entre esses grupos. Assim, "[o 'homem de cor'] não era repelido frontalmente, mas também não era aceito sem restrições" (FERNANDES, 2008, p. 307). Dessa forma, o abismo entre negros e brancos persistiu no período "democrático".

Foi nesse cenário que se moldou o mito da Democracia racial, isto é, “a ideia de que o padrão brasileiro de relações entre 'brancos' e 'negros' se 
A repercussão da disciplina de Sociologia em uma escola no interior do Ceará | Márcio Kleber M. Pessoa \& Manuel Moreira de S. Neto

conformava aos fundamentos étnico-jurídicos do regime republicano vigente" (FERNANDES, 2008, p. 309). Nesse sentido, diz Antonio Sérgio Guimarães, no prefácio ao livro de Fernandes, é um "mito não no sentido de falsidade, como alguns pensam, mas no sentido de uma ideologia dominante, de uma percepção de classe que pensa o seu ideal de conduta como verdade efetiva" (FERNANDES, 2008, p. 12-3). O tipo de sociedade brasileira se contrapunha claramente ao que ocorria nos EUA, onde as leis restringiam a participação dos negros na sociedade, o que embasava o discurso ideológico da Democracia racial. Esse discurso foi tão propagado que a Organização das Nações Unidas decidiu realizar uma grande pesquisa no Brasil sobre o tema, com a finalidade de divulgar a todo o mundo o padrão ideal de Democracia racial existente em nosso país, o Projeto UNESCO (CHOR MAIO, 1999). Os resultados das pesquisas foram frustrantes: o mito da Democracia racial começou a ser desconstruído por meio de apresentação de dados que indicavam profunda desigualdade entre negros e brancos.

A reprodução dessa ideologia acarreta, por exemplo, que o próprio negro seja responsabilizado pelo seu fracasso na sociedade capitalista, visto que, em tese, lhes são ofertados direitos iguais aos dos brancos. Ao mesmo tempo, isenta o branco de responsabilidade, obrigação ou solidariedade em relação ao negro. Por fim, propicia que as relações entre negros e brancos sejam avaliadas de forma superficial e por aparências, descartando-se dados profundos (FERNANDES, 2008, p. 311).

Como se pode perceber, o mito da Democracia racial justificou, em meados do século passado, a manutenção de uma sociedade injusta entre brancos e negros. Todavia, as ciências sociais já refutaram, há bastante tempo, a tese de que há direitos iguais entre brancos e negros no Brasil, ao passo que as ciências biológicas confirmaram que só há uma única raça humana, independentemente de cor da pele ou traços físicos. Contudo, isso não mudou a situação do negro no Brasil e sequer eliminou aquele mito. Sabendo disso, discutiremos a seguir aspectos ligados à disciplina de sociologia no ensino médio. 
A repercussão da disciplina de Sociologia em uma escola no interior do Ceará | Márcio Kleber M. Pessoa \& Manuel Moreira de S. Neto

\section{A disciplina escolar de Sociologia e o tema da Desigualdade racial}

Após 10 anos como disciplina obrigatória do ensino médio, a Sociologia hoje apresenta um cabedal de temas em que podem ser identificados elementos de centralização curricular, tais como as matrizes curriculares estaduais e os livros didáticos distribuídos às escolas públicas através do Plano Nacional do Livro Didático ${ }^{6}$. Neste tópico, apresentamos, em uma breve análise, a forma como a temática da Desigualdade racial está inserida nesse processo.

As Orientações Curriculares Nacionais para o Ensino Médio - OCNEM (BRASIL, 2006), apesar de não se caracterizarem como um centralizador curricular, servem de referência para que seja pensada a inserção do tema destacado neste texto - Desigualdade racial -, no cotidiano escolar da disciplina de Sociologia. Nas OCNEM, consta a proposta de trabalho docente para a disciplina através da utilização dos princípios epistemológicos do estranhamento e da desnaturalização da realidade social, a serem operados metodologicamente pelo uso de teorias, conceitos ou temas construídos pela ciência sociológica. Dessa forma, a orientação de caráter amplo abre espaço para que o professor possa inserir temas relevantes para a realidade vivida pelos estudantes, de acordo com o trabalho pedagógico realizado pelo docente neste estudo de caso. Por fim, destaca-se que este estudo de caso indica que a articulação entre princípios epistemológicos e metodológicos foi priorizada pelo docente, em detrimento da normatização de determinados conteúdos, enquanto proposta fechada de currículo de sociologia ${ }^{7}$.

É preciso, no entanto, perceber que a abertura dada pelo documento, por si só, não fará com que temas como a Desigualdade racial se consolidem como componentes curriculares da disciplina de Sociologia. Assim,

[...] para que haja uma real consolidação de uma, ou mesmo várias, proposta curricular de Sociologia para educação básica precisamos primeiro criar uma cultura escolar em torno desta ciência, o que perpassa as próprias agências formadoras de professores de ciências

\footnotetext{
6 Meucci e Bezerra (2014) levantam a hipótese de que, recentemente, a dinâmica de produção do currículo de Sociologia na educação básica conta com três elementos capazes de produzir a centralização curricular: são eles: o Plano Nacional do Livro Didático (PNLD), o Exame Nacional do Ensino Médio (ENEM) e a forma como os cursos de Licenciatura são estruturados no Brasil.

7 É importante ressaltar que não é o intuito deste texto realizar uma discussão ampla acerca do papel das Orientações Curriculares Nacionais para o Ensino Médio (OCNEM) na construção de um currículo nacional para a disciplina de Sociologia, mas sim destacar sua importância para a abordagem feita pelo professor neste estudo de caso. Para maiores informações sobre a relação entre as OCNEM e o currículo de Sociologia consultar os trabalhos de Moraes e Guimarães (2010) e de Oliveira (2013).
} 
A repercussão da disciplina de Sociologia em uma escola no interior do Ceará | Márcio Kleber M. Pessoa \& Manuel Moreira de S. Neto

sociais, bem como o próprio poder público (OLIVEIRA, 2013, p. 362363).

Oliveira (2013) alerta ainda que todas as proposições positivas das Orientações Curriculares Nacionais para o Ensino Médio podem ser diluídas, se persistir o cenário caracterizado por um baixo número de professores com formação na área ${ }^{8}$, pela ausência de uma tradição de discussões, em âmbito público e acadêmico ${ }^{9}$, sobre a Sociologia escolar.

Nota-se, dessa maneira, que as escolhas relacionadas à seleção dos conteúdos e à proposta curricular adotada estão relacionadas ao modo como a escola se organiza, como o trabalho docente se estrutura, como esses docentes compreendem a função da escola, enfim, como estruturam suas aulas (SILVA, 2009, p. 64).

Após a publicação das OCNEMs, em 2006, é possível perceber que várias Unidades da Federação elaboraram propostas curriculares para a disciplina. De acordo com o levantamento feito por Caridá (2012), quatorze estados ${ }^{10}$ já haviam construído uma proposta programática de conteúdos a serem trabalhados pela disciplina de Sociologia.

Esse movimento de construções curriculares culminou na elaboração das orientações do estado do Ceará, condensado na coleção Escola Aprendente (CEARÁ, 2009), publicação que acompanha, em escala estadual, o movimento de institucionalização curricular da disciplina. É possível perceber, nesse documento, a utilização dos mesmos princípios teóricos e epistemológicos das OCNEMs, como, por exemplo: constatar que se o docente trabalhar "temas pertinentes à realidade social pode despertar grande interesse no educando, criando oportunidades para que ele faça uma

\footnotetext{
8 Em estudo recente, Bodart e Silva (2016) constataram que apenas $11,6 \%$ dos professores de Sociologia cadastrados do Censo escolar realizado pelo MEC/INEP possuíam formação em Licenciatura em Ciências Sociais.

9 Essa realidade tende a mudar com o avanço das pesquisas sobre o Ensino de Sociologia em diversos programas de pós-graduação em todo o Brasil. Handfas e Maçaira (2014, p. 49) realizaram o estado da arte da produção acadêmica sobre o tema entre os anos de 1993 a 2012. As autoras catalogaram 43 trabalhos produzidos no período sendo 41 dissertações de mestrado e duas teses de doutorado. Aqui cabe destacar que mais da metade desses trabalhos (26) foram concluídos entre 2007 e 2012. Além do aumento das pesquisas, outro fator ajuda na ampliação dos espaços de discussão sobre a Sociologia na escola, a ampliação e consolidação de eventos voltados para pesquisadores e professores da educação básica. Destacamos o Encontro Nacional sobre o Ensino de Sociologia na Educação Básica (ENESEB), que em 2019 realizará sua sexta edição, e o Encontro Estadual de Ensino de Sociologia (ENSOC) do Rio de Janeiro, que em 2018 realizou sua sexta edição.

10 Acre, Tocantins, Ceará, Sergipe, Goiás, Mato Grosso, Distrito Federal, São Paulo, Minas Gerais, Rio de Janeiro, Espírito Santo, Paraná, Santa Catarina e Rio Grande do Sul.
} 
A repercussão da disciplina de Sociologia em uma escola no interior do Ceará | Márcio Kleber M. Pessoa \& Manuel Moreira de S. Neto

leitura fundamentada em conceitos e teorias próprias do conhecimento sociológico" (CEARÁ, 2009, p. 86. Grifos nossos).

No que diz respeito à problematização da temática acerca da Desigualdade racial, tanto as Orientações Curriculares Nacionais para o Ensino Médio, quanto a coleção Escola Aprendente fazem menção à importância da presença desse conteúdo nas propostas curriculares adotadas pelo professor de sociologia.

Outros temas que podem ser incluídos em um programa: questão racial, etnocentrismo, preconceito, violência, sexualidade, gênero, meio ambiente, cidadania, direitos humanos, religião e religiosidade, movimentos sociais, meios de comunicação de massa, etc. (BRASIL, 2006, p. 122).

[...] a terceira série aborda o tema complexo da cultura na sua relação com a natureza, bem como os autores brasileiros clássicos das Ciências Sociais (Gilberto Freyre, Florestan Fernandes, Sérgio B. de Holanda, dentre outros) e suas abordagens sobre os graves problemas sociais brasileiros: desemprego, violência, pobreza, racismo, exclusão social, etc. (CEARÁ, 2009, p. 83).

Nota-se que, mesmo com o destaque para o caráter propositivo dos documentos oficiais, a questão da Desigualdade racial e do racismo são lembradas como importantes temas que, em conjunto com conceitos e teorias, atuam como elementos determinantes no movimento de centralização curricular da disciplina via matrizes curriculares estaduais. Tal constatação pode ser encontrada no trabalho de Santos (2012), que, em exercício de análise, mapeou a presença de algumas categorias presentes nas diretrizes curriculares de 14 estados (dentre eles o Ceará) e verificou a presença de conteúdos como desigualdade, cultura, diversidade, ideologia, classes sociais e etnocentrismo, ou seja, conceitos que "abrem as portas" para uma análise da Desigualdade racial nas aulas de sociologia na educação básica.

No mesmo texto, o autor demonstra que tais categorias também estão presentes no edital do PNLD 2012 (o primeiro a incluir a disciplina de sociologia), como sugestão de conceitos, temas e teorias a serem abordados pelas obras que se inscrevessem para aquela seleção. Ao analisar os editais seguintes (PNLD 2015 e 201811), foi constatado que essas categorias

11 Disponivel em: <www.encurtador.com.br/gjyF1>. Acesso em: 27 abr. 2019. Disponível em: <www.encurtador.com.br/jlxP4>. Acesso em: 27 abr. 2019. 
A repercussão da disciplina de Sociologia em uma escola no interior do Ceará | Márcio Kleber M. Pessoa \& Manuel Moreira de S. Neto

permanecem como critérios de eliminação específicos para o componente curricular Sociologia.

\section{Sociologia no ensino médio: apresentação e descrição das aulas}

Neste tópico, serão apresentadas e descritas as aulas de sociologia sobre o tema Desigualdade racial, ministradas na escola estudada. O docente era bacharel e licenciado em Ciências Sociais e mestre em Sociologia. Na $1^{\text {a }}$ série do ensino médio, sociologia conta com uma hora-aula por semana, isto é, cinquenta minutos semanais. O sociólogo lançou mão de várias metodologias para abordar o tema: aulas dialógicas e expositivas, além de ter utilizado variados recursos: reprodução e análise de documentários e filmes, utilização do livro didático de sociologia, problematização de imagens históricas e charges etc. A seguir, a descrição das aulas.

\section{Primeira semana}

Em 10 de novembro, ocorreu a primeira aula sobre o tema Desigualdade racial nas turmas estudadas. O professor utilizou método de aula expositiva e dialógica, escrevendo breve resumo no quadro e, logo após, iniciando uma discussão com os alunos. O tema da aula foi sobre as teorias raciais do século XIX. O docente abordou a teoria da evolução das espécies, de Charles Darwin, discutindo, logo em seguida, sua apropriação por cientistas da época para criarem o chamado Darwinismo social. O sociólogo ressaltou ainda a conjuntura de dominação imperialista europeia, no final do século XIX, e o genocídio praticado pelos nazistas em meados do século $\mathrm{XX}$; ambos os eventos justificados pelo enviesamento da teoria darwiniana. Por fim, expôs que, com o avanço da ciência, a biologia moderna pôde comprovar que só existe uma raça humana, independentemente de cor da pele ou de traços físicos.

Para comprovar, fez o seguinte questionamento às turmas: se um homem copular com uma cadela, pode haver gestação? Muitos alunos estavam em dúvida e alguns chegaram a afirmar que sim. O docente destacou que não pode haver gestação porque homem e cachorro são de espécies diferentes, o que é caracterizado pela quantidade de cromossomos 
A repercussão da disciplina de Sociologia em uma escola no interior do Ceará | Márcio Kleber M. Pessoa \& Manuel Moreira de S. Neto

que cada um possui em seu DNA. O ser humano possui 23 pares de cromossomos, totalizando 46. Outras espécies possuem números distintos. Logo em seguida, perguntou: se uma mulher negra e um homem branco fizerem sexo, pode haver gestação? Se um brasileiro e uma chinesa fizerem sexo, pode haver gestação? As respostas das turmas foram afirmativas. Assim, o professor destacou que esses indivíduos são da mesma raça, seres humanos, independente de características fenotípicas. 12

\section{Segunda semana}

O segundo momento de interação entre o professor e as turmas foi em 17 de novembro. Novamente, utilizou-se o método de aula expositiva e dialógica, expondo um vídeo e discutindo-o. O docente decidiu reproduzir o documentário "Racismo: Uma História - Parte 2: Impactos fatais" (TICKELL, 2007). O vídeo se inicia com a surpreendente imagem de esqueletos humanos espalhados pela areia do deserto da Namíbia; vítimas do contato com o homem "civilizado". Assim, aborda as teorias raciais do século XIX, destacando casos de exterminio de populações não-europeias por europeias. Destaca ainda a teoria da evolução das espécies de Charles Darwin e o "livre uso" dela por cientistas da época, a fim de justificarem a dominação dos não-brancos. Os famigerados estudos de crânios também são citados, além da prática da eugenia, bastante disseminada no final do século XIX e no início do século seguinte, tendo vigorado, por exemplo, leis que proibiam casamentos inter-raciais em vários países, até meados do século XX.

Após a apresentação parcial do documentário ${ }^{13}$, o professor discutiu rapidamente com as turmas. O vídeo serviu basicamente para embasar a discussão da aula anterior sobre as teorias raciais do século XIX. ${ }^{14}$

\footnotetext{
12 Não há consenso sobre o conceito de espécie, visto que há casos em que animais com número de cromossomos diferentes podem se reproduzir, como, por exemplo: o cruzamento do jumento e da égua tem como resultado a mula. Há outros casos. Contudo, o resultado desse cruzamento não necessariamente é uma nova espécie, visto que sempre vem acompanhado de anomalias. A mula, por exemplo, é estéril, logo, não pode dar continuidade à sua "espécie". Esse não é o caso dos seres humanos, que, independentemente de cor e outras características fisicas, possuem 46 cromossomos no DNA.

13 O documentário tem mais de cinquenta minutos de duração, o que tornou inviável sua apresentação por completo. O docente saltou alguns trechos, selecionando aqueles que considerou mais satisfatórios para tratar sobre o assunto da aula.

14 Após a segunda aula, houve um momento de interação entre o professor e as turmas. No sábado, dia 19 de novembro, o docente convidou os alunos para a exibição do filme "Raça" (HOPKINS, 2016), que trata da história do corredor estadunidense negro Jesse Owens, que competiu nas Olimpíadas de Berlim, em 1936, e derrotou atletas alemães que o regime nazista considerava superiores
} 
A repercussão da disciplina de Sociologia em uma escola no interior do Ceará | Márcio Kleber M. Pessoa \& Manuel Moreira de S. Neto

\section{Terceira semana}

Em 24 de novembro, houve mais uma aula de sociologia para as turmas pesquisadas. O tema foi "O mito da Democracia racial no Brasil". O docente optou por novamente escrever no quadro um breve resumo sobre o tema, seguido de uma explanação sua e de um debate com as turmas. Aproveitando a introdução das teorias raciais do século XIX, o professor destacou o cenário nos Estados Unidos e na África do Sul em grande parte do século XX: segregação racial, violência, mas também resistência.

Destacou o cenário brasileiro de ausência de segregação legal, o que gerou o mito da Democracia racial no país. Por conseguinte, ressaltou o contexto da Segunda Guerra Mundial e a - decepcionante - tentativa da ONU de disseminar o "bom exemplo" brasileiro para o resto do mundo por meio do Projeto UNESCO. Além de refutarem a tal "Democracia racial", as pesquisas financiadas por aquela organização ainda analisaram as dificuldades de se combater um racismo "invisivel", como no caso brasileiro, diferentemente dos casos dos Estados Unidos e da África do Sul.

O sociólogo ainda discutiu brevemente sobre ações afirmativas, destacando-as como possibilidade de diminuir a desigualdade estrutural entre negros e brancos no Brasil, quebrando, assim, o círculo vicioso em que a população negra está inserida:

Figura 1 - Círculo vicioso ao qual o negro está "preso" no Brasil

\begin{tabular}{llll} 
& \multicolumn{1}{c}{ Exclusão } & \\
poucos anos de estudo/ & & $\rightarrow$ & desemprego/ \\
baixa qualificação & & & empregos piores remunerados
\end{tabular}

Fonte: elaboração dos autores baseados na discussão realizada pelo professor.

Por fim, o professor fez um exercício de "desnaturalização" de práticas racistas em um país onde "ninguém é racista": aquela piada racista é racismo? Aquele comentário racista, feito em um momento de raiva, é 
A repercussão da disciplina de Sociologia em uma escola no interior do Ceará | Márcio Kleber M. Pessoa \& Manuel Moreira de S. Neto

racismo? Por que, apesar de $89 \%$ dos alunos já terem presenciado ações racistas de outras pessoas e 34\% já terem eles próprios praticado ações racistas, 97\% não se consideram racistas? Por que o racismo sempre está no outro, como diz Schwarcz?

\section{Quarta semana}

O quarto momento da disciplina, no dia 01 de dezembro, foi marcado pela realização de avaliação parcial de conhecimento acerca do conteúdo Desigualdade racial ${ }^{15}$. O professor separou as turmas em grupos de até cinco alunos ${ }^{16}$. Duas questões foram passadas aos grupos, a saber: "Compare as diferenças entre negros e brancos no Brasil e nos Estados Unidos. O que diziam as leis desses países sobre a convivência entre negros e brancos?" e "observe a charge na página 288 do livro (Ver Figura 2). Explique a contradição que o desenhista tentou expor”. Os grupos podiam pesquisar no livro didático: "Tempos modernos, tempos de sociologia" (BOMENY et al, 2013), mais especificamente no capitulo 18: "desigualdades de várias ordens". As respostas do grupo deveriam ser escritas em uma folha e repassadas ao professor.

Figura 2 - Charge utilizada na avaliação parcial

\footnotetext{
15 A norma avaliativa da escola se dava da seguinte forma: deveria ser atribuída nota de zero a dez em cada bimestre. A média da escola, nota mínima para ser aprovado, era seis. Quatro pontos deveriam ser atribuídos em trabalho(s) de responsabilidade do professor da disciplina, a chamada avaliação parcial. Os outros seis pontos eram referentes à realização de uma prova estilo Exame Nacional do Ensino Médio (ENEM) com questões objetivas e separadas por área, a chamada prova bimestral. A disciplina de sociologia contava com cinco questões de múltipla escolha. O ENEM é uma avaliação em larga escala realizada anualmente no Brasil. Seus principais objetivos são: servir de parâmetro para selecionar alunos para o ensino superior e prestar contas à sociedade acerca do nível de aprendizado dos alunos.

16 Vale ressaltar que o professor lançou mão da metodologia de trabalho em grupo por, segundo ele, ser inviável a realização de trabalho individual, visto que, devido à carga horária reduzida da disciplina de sociologia, o docente lecionava em várias turmas. Logo, a realização de atividade individual lhe atribuiria trabalho para além de sua carga horária contratual reservada para a correção das atividades.
} 
A repercussão da disciplina de Sociologia em uma escola no interior do Ceará | Márcio Kleber M. Pessoa \& Manuel Moreira de S. Neto

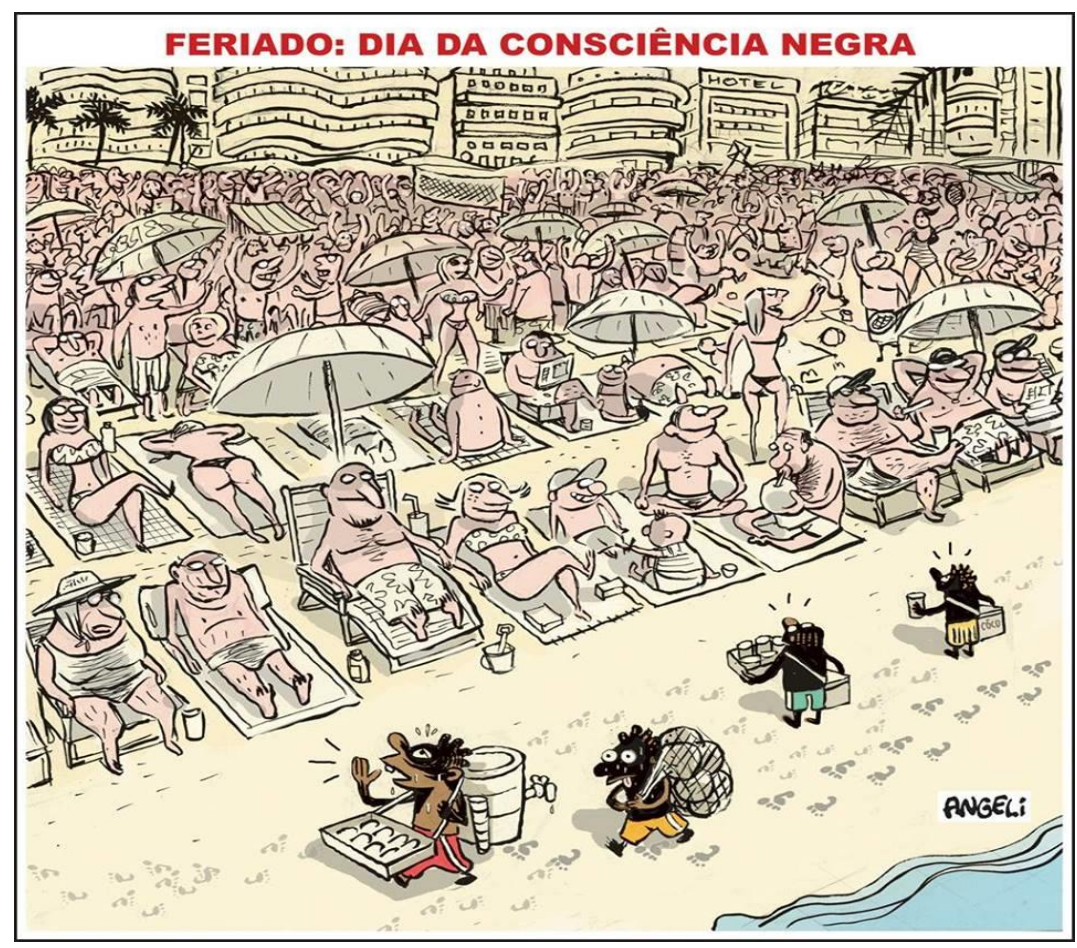

Fonte: Autor: Angeli.

\section{Quinta semana}

Nessa semana, foi realizada outra avaliação de conhecimento, a prova bimestral17. As cinco questões de sociologia abordaram os seguintes subtemas: teorias raciais do século XIX; biologia moderna e a raça humana; racismo nos EUA; racismo no Brasil. A seguir, será transcrita a prova de múltipla escolha de sociologia, com destaque nos itens considerados corretos pelo professor e a porcentagem de acerto por parte dos alunos:

01. O que afirmavam as teorias raciais do século XIX, responsáveis pelo racismo científico? ( $81, \mathbf{9} \%$ dos alunos acertaram)

a) Que brancos e negros eram de raças iguais.

b) Que negros eram de raça superior à dos brancos.

c) Que brancos eram de raça superior à dos negros.

d) Que brancos eram de raça superior à dos negros, mas inferiores a indigenas.

e) Que negros eram de raça superior à dos brancos e à dos indigenas.

02. As teorias raciais serviram de que maneira para os europeus? $(61,1 \%$ dos alunos certaram)

a) Legitimaram seu dominio sobre o resto do mundo, invadindo a África, por exemplo.

17 O professor de sociologia sugeriu que o tema da redação, prova obrigatória aos alunos, fosse Desigualdade racial, o que foi acatado pelo Núcleo Gestor da escola. Além disso, também a pedido do professor de sociologia, o docente da disciplina Lingua Portuguesa incluiu em sua prova um texto sobre racismo. 
A repercussão da disciplina de Sociologia em uma escola no interior do Ceará | Márcio Kleber M. Pessoa \& Manuel Moreira de S. Neto

b) Legitimaram seu isolamento em relação ao resto do mundo, evitando invadir outros países.

c) Legitimaram suas ações de ajuda humanitária ao resto do mundo.

d) Legitimaram seu contato amigável com o resto do mundo.

e) Legitimaram sua política diplomática baseada no diálogo com países africanos.

03. Nos dias atuais, o que afirma a biologia moderna sobre negros e brancos? $(\mathbf{7 3}, \mathbf{6} \%$ dos alunos acertaram)

a) Negros são biologicamente superiores a brancos, pois têm mais cromossomos em seu DNA.

b) Brancos são biologicamente superiores a negros, pois têm mais cromossomos em seu DNA.

c) Negros e brancos são biologicamente iguais, isto é, são da mesma raça, tendo 46 cromossomos em seu DNA.

d) Brancos e negros são da mesma espécie, mas não podem ter filhos porque têm cromossomos diferentes em seu DNA.

e) Brancos e negros são de espécies diferentes, mas podem ter filhos porque têm o mesmo número de cromossomos em seu DNA.

04. Veja a imagem abaixo: $(\mathbf{8 4 , 7 \%}$ dos alunos acertaram)

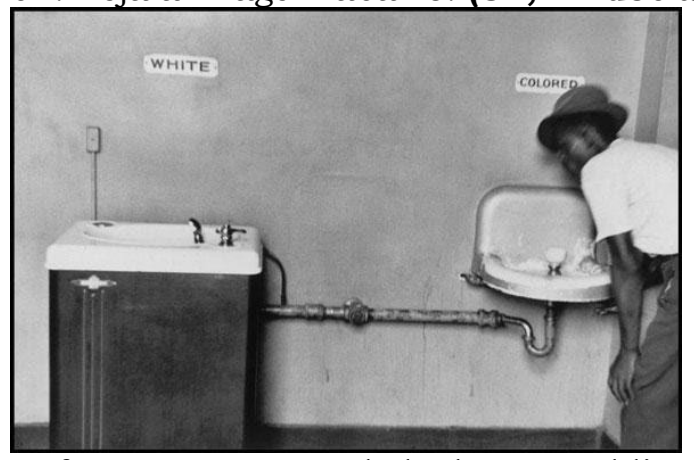

A foto mostra um bebedouro público nos Estados Unidos (EUA) separado para "white" (branco) e "colored" (pessoa de cor). Sabendo disso, marque o item correto sobre as diferenças entre negros e brancos nos Estados Unidos:

a) EUA é um país democrático e nunca teve leis separando negros e brancos.

b) Apesar de existirem leis racistas, na prática, não eram aplicadas pela população.

c) A foto não indica racismo porque era apenas uma questão de higiene embasada pelas leis da vigilância sanitária dos EUA.

d) A foto indica a intensa separação entre negros e brancos nos EUA, conforme previam as leis daquele pais.

e) A foto mostra o nivel de "racismo inverso" dos negros contra os brancos.

05. Veja a imagem abaixo: (81,9\% dos alunos acertaram)

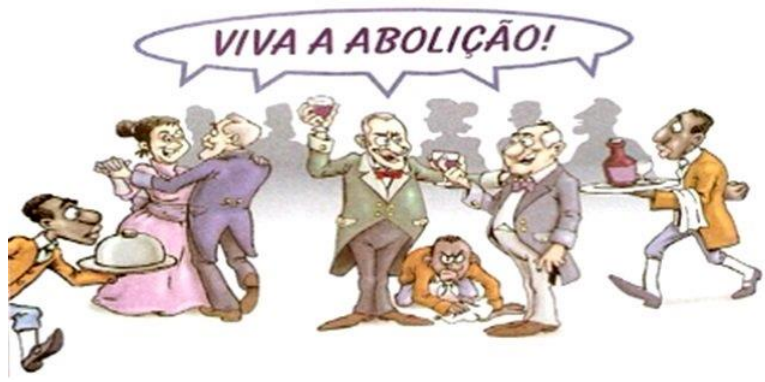

as formas do racismo no Brasil:
Enquanto pessoas brancas "comemoram" a abolição da escravidão, pessoas negras lhes servem em funções subalternas. Agora, responda corretamente sobre 
A repercussão da disciplina de Sociologia em uma escola no interior do Ceará | Márcio Kleber M. Pessoa \& Manuel Moreira de S. Neto

a) A abolição da escravidão eliminou todas as diferenças entre negros e brancos, tornando a sociedade brasileira igualitária.

b) Após a abolição, a sociedade brasileira se tornou verdadeiramente democrática, não havendo mais diferenças entre negros e brancos.

c) O Brasil é tão igualitário na relação entre negros e brancos que serve de exemplo para o mundo, segundo a ONU.

d) Logo após a abolição da escravidão, o Brasil ainda tinha diferenças entre negros e brancos, mas nos últimos anos isso mudou e atualmente já não existe racismo no país.

e) A foto indica que a abolição da escravidão não eliminou as diferenças sociais entre negros e brancos, diferenças que existem até hoje.

No total, setenta e um alunos realizaram a prova de sociologia; cinquenta dos quais acertaram 4 ou 5 questões. Apenas dez alunos acertaram duas questões ou menos. A média de acertos na prova foi de $77,6 \%$.

\section{Sexta semana}

Esta foi a última semana em que o tema Desigualdade racial foi abordado junto às turmas pesquisadas. Aproveitando que o dia 20 de novembro é considerado o Dia da Consciência Negra, os profissionais da escola decidiram realizar um evento sobre o tema, no dia 15 de dezembro ${ }^{18}$. O evento ocorreu à noite e contou com a presença de todos os alunos da escola, de todos os turnos, além de convidados externos. Inicialmente, o professor de Sociologia proferiu uma palestra de trinta minutos sobre o tema Desigualdade racial, abordando basicamente os mesmos assuntos discutidos em sala de aula, mas com o auxilio de uma interessante apresentação de slides contando com fotos históricas, comentários e transcrições de textos de Fernandes e Schwarcz.

Por conseguinte, houve duas apresentações artístico-culturais. A primeira foi produzida pelos alunos da escola com o auxílio do professor de sociologia e buscou fazer uma crítica ao "racismo invisivel" tipicamente brasileiro. Já a segunda apresentação, ápice do evento, foi produzida pela Companhia Revoada de teatro, grupo cearense de dramaturgia. A peça apresentada se intitulava "Índios" e problematizava o etnocídio e o genocídio das populações indígenas brasileiras, além dos impactos negativos ao meio

\footnotetext{
18 Devido a uma greve de durou quase quatro meses, em meados de 2016, o calendário letivo da escola estava bastante desregularizado, o que justificou o "atraso" da realização do evento do Dia da Consciência Negra.
} 
A repercussão da disciplina de Sociologia em uma escola no interior do Ceará | Márcio Kleber M. Pessoa \& Manuel Moreira de S. Neto

ambiente, proporcionados pelo "progresso" capitalista. A intenção foi traçar um paralelo entre a exclusão dos grupos considerados minorias sociais: negros e índios.

\section{Comparação e análise dos dados dos questionários}

Após a exposição dos temas e das metodologias utilizados pelo professor, serão analisadas as respostas dos alunos aos questionários aplicados antes e depois das aulas descritas acima. O segundo questionário foi aplicado no dia 20 de dezembro. Provavelmente devido ao fato de ser a última semana de aula antes do recesso para as festas de final de ano, o número de alunos estava reduzido. Assim, apenas 60 (sessenta) alunos responderam ao segundo formulário. Foram feitas afirmações e os participantes tinham de responder seu grau de concordância ou discordância acerca de cada uma. Quanto maior a concordância, mais se acredita no mito da Democracia racial, e vice-versa.

Tabela 02 - Respostas às questões sobre democracia racial - primeira e segunda aplicações

\begin{tabular}{c|c|c}
\hline \multicolumn{2}{|c}{ Negros e brancos se relacionam de forma pacífica e igualitária no Brasil. ${ }^{19}$} \\
\hline Opções & $1^{\mathrm{a}}$ & $2^{\mathrm{a}}$ \\
\hline Discordo plenamente & $32,4 \%$ & $43,3 \%$ \\
\hline Discordo parcialmente & $39,4 \%$ & $38,3 \%$ \\
\hline Nem discordo nem concordo & $8,5 \%$ & $11,7 \%$ \\
\hline Concordo parcialmente & $11,3 \%$ & $3,3 \%$ \\
\hline Concordo plenamente & $8,5 \%$ & $3,3 \%$ \\
\hline Negros e brancos têm as mesmas oportunidades no mercado de trabalho brasileiro \\
\hline Opções & $1^{\mathrm{a}}$ & $2^{\mathrm{a}}$ \\
\hline Discordo plenamente & $56,3 \%$ & $53,3 \%$ \\
\hline Discordo parcialmente & $16,9 \%$ & $31,7 \%$ \\
\hline Nem discordo nem concordo & $11,3 \%$ & $8,3 \%$ \\
\hline Concordo parcialmente & $8,5 \%$ & $1,7 \%$ \\
\hline Concordo plenamente & $7 \%$ & $5 \%$ \\
\hline Negros e brancos têm as mesmas oportunidades para ingressar no Ensino Superior \\
\hline Opções & $1^{\mathrm{a}}$ & $2^{\mathrm{a}}$ \\
\hline Discordo plenamente & $28,6 \%$ & $40 \%$ \\
\hline Discordo parcialmente & $22,9 \%$ & $26,7 \%$ \\
\hline Nem discordo nem concordo & $17,1 \%$ & $16,7 \%$ \\
\hline Concordo parcialmente & $15,7 \%$ & $5 \%$ \\
\hline Concordo plenamente & $15,7 \%$ & $11,7 \%$ \\
\hline
\end{tabular}

Negros e brancos têm as mesmas oportunidades para se tornarem políticos eleitos Opções $1^{\text {a }}$

19 Legenda: $1^{\mathrm{a}}=$ resultados da $1^{\mathrm{a}}$ aplicação de questionário, anterior às aulas de sociologia sobre o tema; $2^{\mathrm{a}}=$ resultados da $2^{\mathrm{a}}$ aplicação de questionário, posterior às aulas de sociologia sobre o tema. 
A repercussão da disciplina de Sociologia em uma escola no interior do Ceará | Márcio Kleber M. Pessoa \& Manuel Moreira de S. Neto

\begin{tabular}{c|c|c}
\hline Discordo plenamente & $21,4 \%$ & $41,7 \%$ \\
\hline Discordo parcialmente & $24,3 \%$ & $26,7 \%$ \\
\hline Nem discordo nem concordo & $20 \%$ & $10 \%$ \\
\hline Concordo parcialmente & $17,1 \%$ & $6,7 \%$ \\
\hline Concordo plenamente & $17,1 \%$ & $15 \%$ \\
\hline
\end{tabular}

Negros e brancos têm as mesmas oportunidades de ganhar o mesmo salário ao terem o mesmo emprego

\begin{tabular}{c|c|c}
\hline Opções & $1^{\mathbf{a}}$ & $2^{\mathbf{a}}$ \\
\hline Discordo plenamente & $45,1 \%$ & $51,7 \%$ \\
\hline Discordo parcialmente & $23,9 \%$ & $23,3 \%$ \\
\hline Nem discordo nem concordo & $7 \%$ & $8,3 \%$ \\
\hline Concordo parcialmente & $12,7 \%$ & $3,3 \%$ \\
\hline Concordo plenamente & $11,3 \%$ & $13,3 \%$ \\
\hline
\end{tabular}

Negros e brancos têm as mesmas oportunidades para serem aprovados em concursos públicos no Brasil

\begin{tabular}{c|c|c}
\hline Opções & $1^{\mathbf{a}}$ & $2^{\mathbf{a}}$ \\
\hline Discordo plenamente & $21,4 \%$ & $33,3 \%$ \\
\hline Discordo parcialmente & $25,7 \%$ & $33,3 \%$ \\
\hline Nem discordo nem concordo & $14,3 \%$ & $20 \%$ \\
\hline Concordo parcialmente & $22,9 \%$ & $5 \%$ \\
\hline Concordo plenamente & $15,7 \%$ & $8,3 \%$ \\
\hline
\end{tabular}

\begin{tabular}{c|c|c}
\hline Negros e brancos têm a mesma probabilidade de serem vítimas de violência (agressões, assassinatos etc.) \\
\hline Opções & $1^{\mathbf{a}}$ & $2^{\mathbf{a}}$ \\
\hline Discordo plenamente & $46,4 \%$ & $38,3 \%$ \\
\hline Discordo parcialmente & $13 \%$ & $21,7 \%$ \\
\hline Nem discordo nem concordo & $8,7 \%$ & $18,3 \%$ \\
\hline Concordo parcialmente & $18,8 \%$ & $11,7 \%$ \\
\hline Concordo plenamente & $13 \%$ & $10 \%$ \\
\hline
\end{tabular}

Fonte: pesquisa de campo.

Todas as questões fazem afirmações similares: negros e brancos têm iguais oportunidades ou chances com relação a algo. Interpretando os resultados da primeira aplicação, percebe-se grande incidência de respostas que concordam parcial ou plenamente com as afirmações: $20 \%$ concordam que há convivência pacífica e igualitária; $15,5 \%$ que há iguais oportunidades no mercado de trabalho; $31 \%$ acreditam que há isonomia no acesso ao ensino superior; $34 \%$ na chance de serem politicos eleitos; $24 \%$ nas chances de igualdade de renda; quase 39\% acham que há iguais chances de aprovação em concursos públicos; e 32\% concordam que brancos e negros têm a mesma probabilidade de serem vítimas de violência. Além disso, há aqueles que nem concordam nem discordam, que variam entre $7 \%$ e $20 \%$, e os que discordam apenas parcialmente, que variam entre $13 \%$ e $39 \%$.

Esses dados indicam um significativo percentual de alunos (variando entre $15,5 \%$ e $38,5 \%$ do total) que têm tendência a perceber o mito da Democracia racial como real. Contudo, na segunda aplicação, o cenário é distinto: a concordância às afirmações diminui em todos os 
A repercussão da disciplina de Sociologia em uma escola no interior do Ceará | Márcio Kleber M. Pessoa \& Manuel Moreira de S. Neto

questionamentos. Já a discordância só não aumenta em um: aquele sobre violência, em que o índice estacionou. Todavia, a concordância nessa questão diminuiu em mais de 10 pontos percentuais, número incrementado naqueles que não concordavam nem discordavam. Nesse sentido, o percentual de alunos que tendem a acreditar em algum grau naquele mito, após as aulas de sociologia, caiu (variando entre 6,6\% e 21,7\% do total).

Com isso, serão analisadas, a seguir, questões relacionadas às ações afirmativas, que visam à diminuição da desigualdade entre negros e brancos, por meio de ações estatais que beneficiem os negros na medida de sua desigualdade, a saber:

Tabela 03 - Respostas às questões sobre ações afirmativas - primeira e segunda aplicações

Por lei, $20 \%$ das vagas de concursos públicos federais são reservadas para pessoas negras. Em relação a isso, afirma-se: essa reserva de vagas em concursos públicos para negros pode ser considerada preconceito contra os brancos.

\begin{tabular}{c|c|c}
\hline Opp̧ões & $1^{\text {a }}$ & $2^{\text {a }}$ \\
\hline Discordo plenamente & $38 \%$ & $56,7 \%$ \\
\hline Discordo parcialmente & $15,5 \%$ & $10 \%$ \\
\hline Nem discordo nem concordo & $29,6 \%$ & $21,7 \%$ \\
\hline Concordo parcialmente & $8,5 \%$ & $10 \%$ \\
\hline Concordo plenamente & $8,5 \%$ & $1,7 \%$ \\
\hline
\end{tabular}

Por lei, até $50 \%$ das vagas das Universidades Federais podem ser reservadas para negros, as chamadas Cotas raciais. Em relação a isso, afirma-se: todos são iguais, logo, essa reserva de vagas pode gerar segregação entre negros e brancos.

\begin{tabular}{c|c|c}
\hline Opções & $1^{\mathbf{a}}$ & $2^{\mathbf{a}}$ \\
\hline Discordo plenamente & $16,9 \%$ & $23,3 \%$ \\
\hline Discordo parcialmente & $16,9 \%$ & $20 \%$ \\
\hline Nem discordo nem concordo & $21,1 \%$ & $33,3 \%$ \\
\hline Concordo parcialmente & $32,4 \%$ & $16,7 \%$ \\
\hline Concordo plenamente & $12,7 \%$ & $6,7 \%$ \\
\hline
\end{tabular}

Fonte: pesquisa de campo.

A reserva de vagas para negros em seleções visa a fomentar igualdade na disputa por cargos e ocupações. As afirmações buscaram reproduzir argumentos comuns de indivíduos e grupos que se opõem a essas politicas de cotas. A primeira, que tem por objetivo inverter os papéis de desigualdade entre negros e brancos, teve a concordância parcial ou plena de $15 \%$ dos alunos na primeira aplicação. Já em relação à segunda afirmação, que mostra as cotas como fator de segregação social - o que ocorre devido à ausência de políticas de ações afirmativas, caracterizando-se como um contrassenso -, 45\% concordaram em algum grau. O cenário da segundo aplicação é novamente distinto: os percentuais caíram para 11,7\% e 23,4\%, 
A repercussão da disciplina de Sociologia em uma escola no interior do Ceará | Márcio Kleber M. Pessoa \& Manuel Moreira de S. Neto

respectivamente. Em relação às discordâncias, aumentaram em cerca de $10 \%$ entre a primeira e a segunda aplicações. Ademais, a quantidade de pessoas que não concordaram nem discordaram com as afirmações foi alto em ambos os cenários: $29 \%$ e $21 \%$, respectivamente.

Considerando a discussão anterior com os autores, em meados do século XX, o branco não se via impelido a praticar ódio contra o negro, visto que o cenário de concorrência igualitária entre ambos era apenas ilusório, logo, não havia real disputa entre ambos por vagas, ocupações etc. (FERNANDES, 2008). Já no cenário atual brasileiro, a situação é diferente: no início do século XXI, embasadas na Constituição de 1988, algumas leis foram aprovadas a fim de criar um cenário que fomente a igualdade de disputa entre negros e brancos. Isso levou o grupo estabelecido a se manifestar contra essas medidas, reativando o mito da Democracia racial, como se todos tivessem as mesmas oportunidades na sociedade e o fato de o negro não acessar as vagas em disputa fosse apenas uma consequência de sua inabilidade pessoal na disputa.

Apesar de os dados estatísticos indicarem extrema desigualdade entre ambos os grupos, o mito esconde essa diferença e aponta para um cenário ilusório de igualdade. Dessa forma, por parte de quem aciona o mito, não há qualquer tipo de preocupação pela condição do negro. Segundo Darcy Ribeiro (2006, p. 206), "isso ocorre numa sociedade doentia, de consciência deformada, em que o negro é considerado como culpado por sua penúria. Nessas circunstâncias, seu sofrimento não desperta nenhuma solidariedade e muito menos a indignação". Ribeiro escreveu antes da criação das referidas leis; entretanto, o cenário de resistência às cotas ainda existente no Brasil converge com a análise exposta pelo autor.

Por fim, será apresentado o último grupo de questões, as que são relacionadas com as supostas "degeneração" e "inferioridade" do negro.

Tabela 04 - Respostas às questões sobre degeneração e inferioridade racial - primeira e segunda aplicações

A renda média de famílias chefiadas por negros é $40 \%$ menor do que a de famílias chefiadas por brancos. Em relação a isso, afirma-se: essa diferença ocorre porque os negros não se esforçam tanto quanto os brancos.

\begin{tabular}{c|c|c}
\hline Opções & $1^{\mathbf{a}}$ & $2^{\mathrm{a}}$ \\
\hline Discordo plenamente & $76,1 \%$ & $83,3 \%$ \\
\hline
\end{tabular}


A repercussão da disciplina de Sociologia em uma escola no interior do Ceará | Márcio Kleber M. Pessoa \& Manuel Moreira de S. Neto

\begin{tabular}{c|c|c}
\hline Discordo parcialmente & $12,7 \%$ & $1,7 \%$ \\
\hline Nem discordo nem concordo & $4,2 \%$ & $11,7 \%$ \\
\hline Concordo parcialmente & $4,2 \%$ & $1,7 \%$ \\
\hline Concordo plenamente & $2,8 \%$ & $1,7 \%$ \\
\hline
\end{tabular}

Brancos são biologicamente superiores a negros, isto é, brancos são de uma raça superior. Isso explica suas vantagens nos estudos, no trabalho, na renda familiar etc.

\begin{tabular}{c|c|c}
\hline Opções & $1^{\text {a }}$ & $2^{\text {a }}$ \\
\hline Discordo plenamente & $69 \%$ & $76,7 \%$ \\
\hline Discordo parcialmente & $7 \%$ & $5 \%$ \\
\hline Nem discordo nem concordo & $8,5 \%$ & $8,3 \%$ \\
\hline Concordo parcialmente & $4,2 \%$ & $3,3 \%$ \\
\hline Concordo plenamente Fonte: pesquisa de campo.
\end{tabular}

No século XIX, teorias raciais, que se intitulavam "científicas", buscavam comprovar a superioridade do homem ocidental em relação ao não ocidental. O contato entre os europeus e os americanos, por exemplo, gerou várias teorias que culminaram com a propagação da ideia de superioridade dos primeiros. Era a teoria evolucionista, que justificou etnocídios, genocídios e outros eventos de dominação. Havia certa confusão: os evolucionistas se contradiziam em relação ao conceito de "raça". Às vezes, defendiam o monogenismo, destacando apenas as diferenças culturais ou de civilização. Outras vezes, falavam em "raças humanas", defendendo o poligenismo (CASTRO, 2005).

De qualquer forma, aquelas teorias rasas ganharam enorme profundidade nas sociedades da época e, infelizmente, continuam vivas até hoje. Dito isso, serão analisadas as respostas dos participantes da pesquisa: a quantidade de alunos que discordava plenamente das afirmações, na primeira aplicação, era alta: 76\% e 69\%, respectivamente. Pode-se dizer que, em geral, os sujeitos refutavam a "degeneração" do negro ao discordar de sua falta de esforço como justificativa para sua renda familiar inferior. Contudo, o que chama a atenção é a porcentagem de alunos que concorda em algum grau com a superioridade biológica do branco, considerando-o uma raça superior: $15,5 \%$. Já há comprovações científicas que demonstram que negros e brancos pertencem à mesma espécie, a humana. Logo, descreditando as teorias raciais. Contudo, ainda assim, essa quantidade significativa de pessoas concordava com aquela afirmação.

Esse percentual, por ser minoria, não deve ser considerado pouco importante. É um número bastante significativo. Ademais, considerando 
A repercussão da disciplina de Sociologia em uma escola no interior do Ceará | Márcio Kleber M. Pessoa \& Manuel Moreira de S. Neto

ainda os dados na primeira aplicação, se somarmos os que concordam em algum grau e os neutros/indecisos e até com os que discordam parcialmente (não discordando totalmente), $31 \%$ dos alunos possuíam dúvidas, desconheciam, ignoravam ou rejeitavam as teorias cientificas modernas que conferem igualdade biológica entre todos os seres humanos. Certamente, é um dado alarmante.

Acreditar em um discurso ideológico implica desconhecer (ou, em alguns casos, ignorar ou rejeitar) dados que indicam uma realidade distinta. Conforme discutido anteriormente, há dados em demasia acerca da desigualdade social entre negros e brancos. Como, provavelmente, os participantes da pesquisa não tiveram acesso a eles de forma plena e crítica, a disciplina de sociologia no ensino médio, por meio do professor, encarregou-se de apresentar, analisar e discutir aqueles dados junto às turmas. O resultado está exposto na coluna da segunda aplicação: os que concordaram em algum grau com as afirmações caíram para 3,4\% e 10\%, respectivamente. Apesar disso, na afirmação sobre a "degeneração" do negro, quase triplicou a quantidade de alunos que nem concordaram nem discordaram, além de os que discordaram em algum grau ter diminuído, passando de $88,8 \%$ para $85 \%$.

\section{Considerações finais}

Após a exploração intensa do caso estudado, destaca-se que a intervenção da disciplina de sociologia no ensino médio foi relativamente exitosa na escola estudada. Isso ocorre, principalmente, devido à desconstrução parcial do mito da Democracia racial, comprovado pela diferença dos dados da primeira e da segunda aplicação de questionários.

O fato de haver a persistência de alunas e de alunos que, de alguma forma, não conseguiram realizar aquela desconstrução não se traduz em fracasso na intervenção. Temos que considerar as adversidades ligadas à questão, a saber: $73 \%$ dos alunos afirmaram já ter estudado o tema "Desigualdade racial" antes das aulas de sociologia aqui analisadas. Contudo, mais de dois terços dos alunos concordaram em algum grau que as aulas de sociologia sobre o tema "contribuíram com informações que o aluno nunca havia tido acesso antes na escola, na televisão, na familia etc.", 
A repercussão da disciplina de Sociologia em uma escola no interior do Ceará | Márcio Kleber M. Pessoa \& Manuel Moreira de S. Neto

o que pode significar que esses alunos tinham acesso a discussões rasas ou, até mesmo, viciadas, visto que o professor discutiu em sala a produção sociológica básica brasileira sobre o tema. Essa quantidade alta de alunos que nunca havia tido acesso aos dados apresentados pelo professor de sociologia converge com a discussão realizada por Schwarcz de que o tema é um verdadeiro tabu em nossa sociedade. Devido a isso, 83\% dos jovens concordaram, em algum grau, que "os conhecimentos estudados sobre Desigualdade racial na disciplina de sociologia foram muito importantes" para a vida deles. Outros dados que apontam para o relativo êxito são os seguintes:

Tabela 05 - Respostas às questões sobre racismo no cotidiano - primeira e segunda aplicações

\begin{tabular}{c|c|c}
\hline Pergunta & $1^{\text {a }}$ aplicação & $2^{\text {a aplicação }}$ \\
\hline Você se considera racista? & $3 \%$ & $18,6 \%$ \\
\hline Você já praticou alguma ação racista? & $34 \%$ & $65 \%$ \\
\hline Você já sofreu alguma ação racista? & $45 \%$ & $58 \%$ \\
\hline \multicolumn{2}{c}{ Fonte: pesquisa de campo. }
\end{tabular}

Como se pode perceber, visivelmente os alunos passaram a ter outro entendimento sobre o que é racismo. Os dados da segunda aplicação mostram indivíduos com maior rigor ao analisarem situações cotidianas de suas vidas. Isso converge com uma das problematizações realizadas pelo professor de sociologia: aquela piada racista é racismo? Aquele comentário racista, feito em um momento de raiva, é racismo? Por que o racismo sempre está no outro?

Por fim, destaca-se que vários outros fatores contribuem para a socialização dos alunos, sendo os 50 minutos semanais de aula da disciplina estudada limitados na tarefa de desnaturalização de preconceitos, mas que demonstraram ter uma repercussão positiva nesse objetivo. Ademais, mesmo na escola há relações de poder que contribuem para a permanência do tabu destacado por Schwarcz e para a reprodução de preconceitos, conforme os pesquisadores puderam observar, a saber: no final de novembro, durante a realização de uma reunião de planejamento coletivo com os professores da área de Ciências Humanas, debatia-se a realização de um evento alusivo ao Dia da Consciência Negra. O professor de História comentou que, naquela cidade, havia diferenças salariais entre negros e brancos, segundo o 
A repercussão da disciplina de Sociologia em uma escola no interior do Ceará | Márcio Kleber M. Pessoa \& Manuel Moreira de S. Neto

Instituto Brasileiro de Geografia e Estatística (IBGE). Imediatamente, um dos coordenadores escolares o interrompeu dizendo que, naquela cidade, não havia diferenças entre negros e brancos. Visivelmente, todos os professores da área de Ciências Humanas ficaram incomodados com aquela afirmação, o que deu início a um fervoroso debate. Em certo momento, o professor de sociologia perguntou ao coordenador em quais dados ele se embasava para afirmar aquilo, pois o professor de História se embasava em dados de investigação do IBGE. O coordenador, então, respondeu que se embasava na "realidade"20 e que os dados do IBGE deveriam ser criticados também, afirmando que os negros podiam mentir sobre sua condição social para conseguirem benefícios. O professor de sociologia, então, indagou: " $E$ só os negros mentem? Tem certeza de que não há racismo [nesta cidade]?", indicando que o coordenador estava tendo uma postura preconceituosa. Após isso, o debate foi finalizado... pelo menos naquele ambiente.

\section{Referências}

BOMENY et al. (Coord.) Tempos modernos, tempos de sociologia: ensino médio: volume único. $2^{\text {a }}$ ed. - São Paulo: Editora do Brasil, 2013.

BRASIL. Secretaria de Educação Média e Tecnológica. Orientações Curriculares Nacionais: Ensino Médio. Brasília, DF, 2006.

BODART, Cristiano das Neves; SILVA, Roniel. Um raio-x do professor de Sociologia brasileiro: condições e percepções. Estudos de Sociologia, Recife, v. 2, n. 22, p. 197-233, 2016.

CARIDÁ, Ana Carolina Bordini Brabo. O Currículo de Sociologia no Ensino Médio. In: SOUSA, Fernando Ponte de (Org.). Sociologia: conhecimento e ensino. Florianópolis: Editora Em Debate, 2012.

CASTRO, Celso. (Org.) Evolucionismo cultural: textos de Morgan, Tylor e Frazer. Rio de Janeiro: Zahar, 2005.

CEARÁ. Secretária da Educação. Metodologias de apoio: matrizes curriculares para o ensino médio. Fortaleza: SEDUC, 2009.v.1. Coleção escola aprendente.

CELlARD, A. A análise documental. In: POUPART, Jean et al. A pesquisa qualitativa: enfoques epistemológicos e metodológicos. Petrópolis-RJ: Vozes, 2014.

\footnotetext{
20 Ficou claro que ele estava se referindo à sua percepção. Acriticamente, o profissional desconsiderou suas pré-noções e limitações ao afirmar que sua percepção era a "realidade".
} 
A repercussão da disciplina de Sociologia em uma escola no interior do Ceará | Márcio Kleber M. Pessoa \& Manuel Moreira de S. Neto

CHOR MAIO, Marcos. O Projeto UNESCO e a Agenda das Ciências Sociais no Brasil dos anos 40 e 50. In: RBCS. v. 14, n. 41, outubro, 1999.

FERNANDES, Florestan. A integração do negro na sociedade de classes. (o legado da "raça branca"). v. 1. 5 ed. São Paulo: Globo, 2008

GOLDENBERG, Mirian. A arte de pesquisar: como fazer pesquisa qualitativa em Ciências Sociais. 8. ed. Rio de Janeiro: Record, 2004.

GUIMARÃES, Antonio Sérgio. Como trabalhar "raça" em sociologia. In: Educação e pesquisa. São Paulo, v.29, n.1, p. 93-107, jan./jun. 2003.

HANDFAS, Anita; MAÇAIRA, Julia Polessa. O estado da arte da produção científica sobre o ensino de Sociologia na educação básica. Revista BIB, São Paulo, no 74, pp. 43-59, 2014.

MEUCCI, Simone; BEZERRA, Rafael Ginane. Sociologia e educação básica: hipóteses sobre a dinâmica de produção de currículo. Revista de Ciências Sociais, Fortaleza, v. 45, n. 1, p. 87-101, 2014.

MORAES, Amaury César; GUIMARÃES, Elisabeth da Fonseca. Metodologia de Ensino de Ciências Sociais: Relendo as OCEM-Sociologia. In: MORAES, Amaury César (coord.). Sociologia: ensino médio (Coleção explorando o ensino; v.15). Ministério da Educação: Secretaria de Educação Básica, Brasília, 2010.

OLIVEIRA, Amurabi. O currículo de Sociologia na escola: um campo em construção (e disputa). Espaço do curriculo, v.6, n.2, p.355-366, mai./ago. 2013.

RAÇA. Direção: Stephen Hopkins. Produção: Kate Garwood; Stephen Hopkins. Canadá; Alemanha: FORECAST PICTURES, 2016.

RACISMO: Uma História; Parte 2: Impactos fatais. Direção: Paul Tickell. Produção: Sue Davies. Inglaterra: BBC FOUR, 2007.

RIBEIRO, Darcy. O povo brasileiro. São Paulo: Companhia das Letras, 2006.

SANTOS. Mario Bispo dos. Diretrizes Curriculares estaduais para o ensino de sociologia: em busca do mapa comum. In: Percursos. Florianópolis, v.13, n.01, p. 40-59, jan/jun. 2012.

SCHWARCZ, Lilia Moritz. Nem preto nem branco, muito pelo contrário. Cor e raça na sociabilidade brasileira. São Paulo: Claro Enigma, 2012.

SILVA, Ileizi L. F. Fundamentos e metodologias do ensino de sociologia na educação básica. In: HANDFAS, Anita e OLIVEIRA, Luiz Fernandes de (Orgs). A Sociologia vai à escola: história, ensino e docência. Rio de Janeiro: Quatert: Faperj, 2009. 
A repercussão da disciplina de Sociologia em uma escola no interior do Ceará | Márcio Kleber M. Pessoa \& Manuel Moreira de S. Neto

YIN, Robert. K. Estudo de caso: planejamento e métodos. 2. ed. Porto Alegre: Bookman, 2001. 